\title{
Aikuiskasvattajien yhteiskunnallinen sitoutuminen $^{1)}$
}

\begin{abstract}
Mezirov, Jack, 1985, Aikuiskasvattajien yhteiskunnallinen sitoutuneisuus. Aikuiskasvatus 5, 3, 102-106. - Artikkelissa tarkastellaan arvojen omaksumista lapsuudessa ja kriittisen tietoisuuden herättämistä aikuisuudessa. Erityisen tärkeänä pidetään dialogian kautta tapahtuvaa oppimista ja yhteiskunnallisen toiminnan aikaansaamista.
\end{abstract}

\section{Arvojen omaksuminen}

Tässä esitelmässä väitän, että aikuiskasvattajina meidän yhteiskunnallinen sitoutuneisuutemme pohjautuu aikuisen oppimisprosessin perusluonteeseen ja meidän tehtäväämme helpottaa tätä prosessia.

Kehityspsykologit ovat havainneet että kaikki kognitiiviset rakenteet läpikäyvät kehityksellisiä muutoksia. Ymmärtääksemme näiden rakenteiden perusteita, tulee meidän tarkastella itse sosialisaatioprosessia. Lapsuudessa meidät sopeutetaan eri tapoihin tajuta todellisuus erilaisten merkitysskeemojen ja -perspektiivien kautta, jotka me täysin automaattisesti omaksumme vanhemmilta, opettajilta, roolimalleilta sekä tovereilta. Meihin vaikuttavat yksilöt ovat väistämättä sen yhteisön ja aikakauden tuotteita, jossa he itse elävät. Jokaiselle kulttuurilla ja aikakaudelle on oma konservatiivinen ilmapiirinsä: erilaisia sovinnaisuuksia, tabuja, epäoikeudenmukaisuuksia, nurkkakuntaisuuksia, ratkaisumalleja, ideologioita ja vääristymiä. Kielen kehittymätön rakenne ja puutteellinen dialogi rajoittavat ymmärrettävyyttä piilevästi mutta merkittävästi. Tällaiset vaikutteet vahvistuvat ja legitimisoituvat erilaisten vallitsevien sosiaalisten käytäntöjen ja instituutioiden kautta - jotka usein määräävät, säilyttävät ja vahvistavat niistä lähtevät arvot ja järjestelmät.

\footnotetext{
${ }^{1)}$ Esitelmä pidetty ensimmäisessä International League for social commitment in adult education'in konferenssissa Ruotsissa heinäkuussa 1985.
}

Tämän lisäksi jokaisella vanhemmalla tai roolimallilla on omat luontaiset kompleksinsa, pelkonsa, estonsa, kompensointimekanisminsa, riippuvaisuutensa, ennakkoluulonsa, oppimistyylinsä, roolinomaksumistapansa sekä tapansa pettää itseään.

Nämä psyykkiset tekijät vaikuttavat tapaan, millä opimme oppimaan. Yllämainittujen, yhteisen historiamme tuloksena syntyneiden kulttuurivaikutteiden ohella, lapsuudenkokemuksemme "muiden tärkeiden henkilöiden"' kanssa muodostavat vaikutuskentän, jolla merkitysrakenteitamme muokataan. Voimme pitää tätä psyykkiskulttuurista vaikutuskenttää henkilökohtaisena oppimisympäristönämme. Tapa, jolla opimme näkemään itsemme ja todellisuutemme aikuisina on suureksi osaksi monien yhteensattumien summa, jonka taustatekijöinä ovat historia, elämäkerta, kulttuuri, kieli ja psyykkiset tekijät.

Omaksumamme merkitysskeemat näyttäisivät toimivan tietoisuuden ulkopuolella; niiden tehtävänä tuntuu olevan määritellä mitä käsitimme ja kuinka me sen käsitämme. Käytämme merkitysskeemojemme valikoimaa luokitellaksemme erilaisia asioita ja tapahtumia siten, että se, mikä tulee tietoisuuteemme on todellisuúdessa vain valikoidusti tulkittu versio siitä, mitä havaitsemme. Daniel Goldman kuvailee tämän prosessin osuvasti:

Skeemat ja kiinnostukset toimivat keskenään eräänlaisessa monimutkaisessa tanssissa. Mielenkiinnon kohdistaminen johonkin tiettyyn osakokemukseen - esimerkiksi on lounasaika ja olet nälkäinen - 
aktivoi toisia, asiaankuuluvia skeemoja - esim. ajatuksia läheisistä ravintoloista tai siitä, mitä sattuu olemaan jääkaapissa. Skeemat vuorostaan määräävät mielenkiintomme kohteet. Jos kävelee kadulla nämä skeemat aktivoituneina, huomio kiinnittyy ravintoloihin, ei muihin kadun varrella oleviin liikkeisiin. Jos menet jääkaapille, mielenkiinto kohdistuu leikkeleisiin ei niinkään päivälliseksi varattuun paistiin. Skeemojen pohjalta tehdään valintoja; ne määräävät mielenkiinnon laajuuden. Kiinnostusten ja skeemojen välinen toiminta sijoittaa ne itse asiassa itsepetoksen keskeiseksi tekijäksi. Skeemat eivät ainoastaan määrää sitä, mitä me huomaamme; ne saattavat myös määrätä sen, mitä me emme huomaa. (1985)

Merkitysskeemat eivät pelkästään sattumanvaraisesti tai valikoivasti määrää kiinnostuksemme laajuutta, vaan yleisemmällä tasolla olevat merkitysperspektiivit ovat yhtälailla sattumanvaraisia ja valikoivia tavalla, jolla ne luokittelevat ja yhdistävät eri asioita sekä määrittävät syysuhteita. Ne muodostavat pohjan, jolla monimutkaiset, päättelykykyä edellyttävät tehtävät voidaan pelkistää yksinkertaisiksi arvoiksi. $\mathrm{Ne}$ varustavat meidät tietyillä odotuksilla - liittyen syy- ja seuraussuhteisiin, erilaisiin tapahtumaketjujen skenaarioihin, ja siihen millaisia oletamme muiden ihmisten olevan (esim. Archie Bunker-tyyppi, autokauppias, anoppi, ikuinen häviäjä) - odotuksin, joilla on taipumus muodostua itsetoteutuviksi ennusteiksi. Merkitysperspektiivit antavat meille kriteerejä, joilla arvioimme oikean ja väärän, hyvän ja pahan, kauniin ja ruman, toden ja epätoden sekä sopivan ja epäsopivan. $\mathrm{Ne}$ myöskin määräävät tavan, millä arvioimme oman itsemme. Eräs tärkeimmistä jokapäiväiseen elämäämme vaikuttavista merkitysperspektiiveistä on oma idealisoitu minä-kuvamme — ydinkäsitys itsestämme aikuisina. Merkitysskeemat ja -perspektiivit ovat psyykkiskulttuuristen olettamusten rakenteita, joiden puitteissa omat aiemmat kokemuksemme mukauttavat ja muuntavat uusia kokemuksia. Nämä merkitysrakenteet eivät ole pelkästään kognitiivisia; niillä on myös vahvasti konatiivisia ja affektiivisia piirteitä. Ne valmistavat meidät toimintaan. Kun lähestymme uusia kokemuksia, merkitysrakenteemme muuttuvat oppimisrakenteiksemme.

Koska omaksumme merkitysrakenteemme epäkriittisesti lapsuusajan sosialisaatioprosessin aikana, nämä saattavat olla epäluotettavia, vääristyneitä, rajoitettuja ja riippuvaisuutta tuottavia. Ne useinkin kuvastavat ennakkoluuloja, muuttumattomia asenteita, päätelmävirheitä, itsepetosta, vääristäviä ideologioita, sekä lapsuuden ajan estoja, jotka heijastuvat ihmisten käyttäytymisenä vielä aikuisiässä.

Lapsuuden ajan kehitykseen kuuluu uusien merkitysskeemojen omaksuminen ja vanhojen erittely ja laajentaminen. Piaget, Kohlberg ja muut kehityspsykologit ovat kuvailleet tapaa, miten tällaiset merkitysrakenteet hankitaan ja muunnetaan ajan kuluessa lapsen tietoisuuden ulkopuolella, siten että uudet tavat tulkita todellisuutta tulevat tiedostamatta vanhojen tapojen tilalle.

Aikuisiässä, uusi kehityksen ulottuvuus mahdollistaa ymmärryksemme ja vaikutustietoisuutemme laajenemisen, tekemällä meidät tietoiseksi lapsuuden aikana epäkriittisesti omaksutuista merkitysrakenteista ja -perspektiiveistä, jotta voisimme ne kriittisesti analysoida ja hyväksyä. Juuri tämä tekee aikuisoppimisesta ainutlaatuisen tapahtuman, ja tästä syystä sillä on suuri merkitys koko aikuiskasvatuksessa. Asioiden yhdistelykyky ja kriittinen pohdiskelu ovat aikuisominaisuuksia jotka näyttävät olevan nuoruusiässä hankittujen hypoteettisdeduktiivisten ajatusprosessien tärkein kehitystulos. Ne ovat aikuisen oppimisproséssin keskeisiä tekijöitä. Nuoruusiässä formaalisten toimintojen kehittyminen tekee mahdolliseksi ymmärtää, kuinka vallanpitäjät ovat luoneet ihmisen ajattelua ja toimintaa ohjailevat säännökset abstraktien periaatteiden pohjalta $-\mathrm{ja}$ asettaa tämän prosessin oikeellisuuden kyseenalaiseksi. Aikuisina voimme tulla kriittisesti tietoisiksi olettamuksista, joihin nämä periaatteet itse nojaavat. Voimme ulottaa kriittisen tietoisuutemme sisäistämiimme ideologioihin, malleihin, uskomuksiin, orientaatioihin, estoihin ja viitekehyksiin. Aikuisina voimme paremmin ymmärtää miten ja miksi olemme hankkineet omat merkitysperspektiivimme, niiden toimivuuden sekä tavan millä ne ovat muokanneet meidän ja muiden ihmisten elämää.

Kun kriittisen tietoisuuden periaatetta sovelletaan instrumentaaliseen oppimiseen (ts. tarkoituksena on kontrolloida tai manipuloida ympäristöä tai kanssaihmisiä), voimme testata sen paikkansapitävyyden yrittämällä osoittaa, että jokin väittämä vastaa todellisuutta; voimmeko väittämää soveltamalla saada tarkemman ennusteen odotetusta lopputuloksesta? Ratkaisua soveltamalla voimme empiirisesti osoittaa, onko väittämä tosi, ja perustuuko se oikeaan analyysiin. Tämä parempaan ennustamiseen ja kontrolliin tähtäävä syy- ja seuraus- 
suhteiden manipulointi on analysointitapa, jolla vahvistetaan totuus luonnontieteissä. Mutta instrumentaalinen oppiminen on vain eräs aikuisoppimisen osa-alue.

Suurimmaksi osaksi, aikuisten tärkeintä oppimista ei kuitenkaan ole instrumentaalinen oppiminen, vaan oppimista joka käsittää arvoja, moraalista päätöksentekoa, ihanteita, tunteita, ja sellaisia abstraktikäsitteitä kuin rakkaus, vapaus, oikeus, myötätunto, tasa-arvo, ihmisoikeudet ja demokratia. Miten tiedämme, että näitä käsitteitä koskeva mielipide pitää paikkansa (tai on tunteiden osalta aito)? Tässä Jurgen Habermas (1984) esittää vakuuttavasti, että mielipide voidaan todistaa oikeaksi vain konsensuksen avulla - ihanteellisesti, tähän päädytään asiantuntevien, objektiivisten ja järkevien ihmisten käyvän, vapaaehtoisen, täysimuotoisen ja jatkuvan keskustelun kautta. Tällä prosessilla on analogian valamiehistön tai tutkimuskomission päätöksissä; siis erilaisia mielipiteitä omaavat henkilöt tutkivat jonkin asian, kuuntelevat todisteita ja kuulustelevat todistajia, tarkoituksenaan ratkaista joidenkin syytösten paikkansapitävyys.

\section{Tavoitteena oppimiskeskustelu}

Dialogisessa oppimisessa on ratkaisevan tärkeää varmistaa mitä muut tarkoittavat kun he kommunikoivat kanssamme puheen, tekstin, runojen, draaman tai taiteiden kautta. Dialogin ihanneolosuhteet sisältyvät inhimillisen kanssakäymisen perusluonteeseen. Dialogin oppiminen on niin tärkeää pyrkiessämme ymmärtämään itseämme aikuisina, että sen ihanneolosuhteet tarjoavat kriteerit, joilla voimme rakentaa arvojärjestelmän millä voimme arvioida sekä aikuiskasvatusta että yhteiskuntaa missä se toimii.

Jokapäiväisessä elämässä pidämme aivan normaalina, että muut esittävät omia ehdotuksiaan tai mielipiteitään. Mielipide siitä, mikä on totta, oikein, korrektia, aitoa tai sopivaa voidaan esittää raporteilla, kielloilla, selityksillä tai ennusteilla, tai niihin voidaan viitata käskyillä, suosituksilla tai puolusteluilla. Kun jonkin mielipiteen ymmärrettävyys, totuus tai aitous, tai sen esittäjän rehellisyys tai vilpittömyys asetetaan kyseenalaiseksi, dialogi juuttuu paikoilleen. Tällaisissa kriisitilanteissa kun mielipiteen oikeellisuus joudutaan selkeästi perustelemaan, ryhdymme kysymystä pohdiskelevaan, erityiseen keskusteluun. Ihanteellisesti, aivan kuten valamiehistön jäsenet, vältämme ennalta tuomitsemista ja teemme päätöksemme mielipiteen oikeellisuudesta esitettyjen todisteiden ja perustelujen pohjalta. Ihanteellisesti päätyisimme konsensukseen, mihin kuka tahansa järkevä, asiantunteva ja objektiivinen tuomari yhtyisi. Tämänlainen oppimiskeskustelu on aikuiskasvatuksen tavoitteena.

Täysimuotoisen, vapaan keskustelun ihanneolosuhteet ovat ratkaisevan tärkeitä aikuiskasvatukselle, koska ne ovat samalla oppimiskokemuksen ihanneolosuhteet. Ne ovat myöskin elinikäiseen oppimiseen sitoutuneen oppimisyhteiskunnan ihanneolosuhteet. Tässä yhteydessä "ihanne" tarkoittaa konkreettista toimintaa, ei saavuttamatonta täydellisyyttä.

Ihannekeskustelun osapuolten yhteisenä päämääränä olisi saavuttaa konsensus, joka pohjautuisi pelkästään todisteisiin ja perustelujen vakuuttavuuteen. Heillä olisi tarkat ja täydelliset tiedot keskustelun aiheesta, keskustelu tapahtuisi vastavuoroisuus-periaatteen pohjalta - jokaiselle osanottajalla olisi yhtäläinen mahdollisuus tulkita, selittää, vastustaa, kiistää, ilmaista mielipiteitään, ja pitää puheenvuoroja. Osanottajia ei painostettaisi millään tavoin. He toisivat keskusteluun tärkeitä aikuisominaisuuksia - kyvyn väitellä järkiperäisesti kilpailevista oikeellisuusväitteistä, perustaen argumenttinsa esitettyihin todisteisiin, kyvyn arvostella erilaisia kulttuurisidonnaisia uskomuksia ja perusteita, sekä kyvyn olla riittävän rehellinen välttyäkseen esittämästä vääristyneitä näkökantoja jotka saattavat johtua heidän omista estoistaan, vääristyneistä kompensointimekanismeistaan, tai muista itsepetosmuodoista.

Mikäli näitä ehtoja ei tiedosteta ja noudateta, oppimiskokemuksesta tulee puutteellinen. Kun sosiaaliset instituutiot vaikeuttavat aikuisopiskelijoiden mahdollisuuksia tulkita omat kokemuksensa dialogin kautta, ne tukahduttavat mitä keskeisimmän inhimillisen perustarpeen, ja niitä tulisi muuttaa siten, että ne ottaisivat tämän tarpeen paremmin huomioon.

Sellaiset aikuiskasvatuksen päämäärät kuin henkinen kehitys, kognitiivinen ja moraalinen kehitys, itsensä toteuttaminen, vapautuminen, demokraattinen osallistuminen ja yhteiskunnallinen toiminta, sekä sellaiset sosiaaliset ja poliittiset päämäärät kuten ihmis- ja kansalaisoikeudet ovat erittäin tärkeitä, mutta ne ovat vain välineellisiä. Niiden yhteinen tarkoitus on ylläpitää olosuhteita, joiden avulla aikuinen voi ymmärtää omat kokemuksensa osallistumalla vapaaseen, täysimuotoiseen dialogiin. Dialogi edustaa ihmisen inhimillisintä piirrettä: kykyä oppia kokemusten merkitys, ja reali- 
soida elämän potentiaalinen arvo kommunikoinnin avulla.

Meillä on ikävä tapa alentaa vapaus itsemääräämisoikeudeksi, ja itsemääräämisoikeus vapautukseksi sosiaalisista pakotteista. Mutta vapautta ja isemääräämisoikeutta ei pidä pelkästään nähdä "vapautumisena jostakin'; niitä tulisi pitää välttämättöminä ennakkoehtoina vapaalle, täysimuotoiselle osallistumiselle ihannedialogiin. Määritelmänsä mukaisesti, dialogi on eräs sosiaalisen vuorovaikutuksen muoto. Omat merkitysrakenteemme ovat sosiaalisen vuorovaikutuksen tulosta. Vapaus ja itsemääräämisoikeus ovat sosiaalisen vuorovaikutuksen ennakkoehtoja; ne eivät merkitse pakoa yhteiskunnasta.

Esteet ihannedialogille - ja samalla vapaudelle ja totuudelle - ovat usein luonteeltaan poliittisia tai taloudellisia: laitostettuja ideologioita, tapoja, käytäntöjä ja järjestelmiä, jotka johtavat sortoon, pakotteisiin, vieraantumiseen, ihmis- ja kansanlaisoikeuksien kumoamiseen, vääryyksiin, ja epäsuhteeseen ihmisten mahdollisuuksissa saada turvallisuutta, terveyspalveluja, koulutusta, asunto tai työpaikka. Akuutti puute ja turvattomuus, epätoivo, vieraantuminen, pelko, sairaus ja tietämättömyys voivat saattaa dialogisen oppimisihanteen naurunalaiseksi. Nämä ovat yhteisiä ongelmia, jotka voidaan parhaiten ratkaista yhteisen toiminnan avulla.

\section{Aikuiskasvattajan velvollisuudet}

Aikuiskasvattajien tehtävänä on edesauttaa aikuisoppimista. Kun oppimista rajoitetaan ja yhteiskunnan laitokset, käytännöt tai järjestelmät tekevät oppimisen itsestään riippuvaiseksi, joutuu aikuiskasvattaja pakostakin puuttumaan asioiden kulkuun. Auttaessamme aikuisopiskelijoita muuttamaan huonosti toimivia merkitysrakenteita, eräänä tehtävänämme on auttaa heitä tajuamaan, että samoja ongelmia on myös niissä instituutioissa, jotka laillistavat ja tukevat riippuvuutta tuottavia merkitysperspektiivejä. Opiskelijat haluavat usein ryhtyä yhteiseen toimintaan muuttaakseen niitä. Meidän velvollisuutenamme on auttaa heitä oppimaan, miten tämä on mahdollista.

Aikuisoppiminen käsittää mielestäni kolme sosiaalisen sitoutuneisuuden ulottuvuutta. Ensiksi, jokaisella aikuiskasvattajalla jokaisessa oppimisympäristössä on perusvelvollisuus ylläpitää mahdollisimman ihanteellisia keskusteluolosuhteita eri oppimistilanteissa. Ratkaise- van tärkeä tehtävä on auttaa opiskelijoita siirtymään kohti merkitysperspektiivejä, jotka helpottavat heidän osallistumistaan keskusteluun. Tämä merkitsee, että edetään pidemmälle kuin se, että täytetään opiskelijan itsensä alkuperäiset oppimistoivomukset. Opettajan on ymmärrettävä, että on välttämättömän tärkeää edetä pidemmälle kuin opiskelija on itse toivonut. Näin voimme auttaa aikuisia tulemaan kriittisesti tietoisiksi heidän tarpeidensa taustatekijöistä, ja auttaa heitä ymmärtämään, miten he ovat päätyneet nykyiseen todellisuuteensa. Aikuisopiskelijoiden tulee tietää, kuinka erilaiset kulttuurivaikutteet ovat muokanneet heidän tapaansa ymmärtää asioita. Opettajina meidän tulee olla kiinnostuneita koko oppimisprosessista, myös kriittisestä pohdiskelusta. Tällä sitoutumalla on keskeinen merkitys koko aikuiskasvatukselle - toivotuilla oppimistuloksilla ei edistetä kriittistä pohdiskelua, kuten ei myöskään kriteerisidonnaisilla arvostelujärjestelmillä tai muilla toimilla, jotka perusteettomasti pohjautuvat uskomukseen, että kaikki oleellinen oppiminen voidaan yhtäläistää mitattavissa oleviin käyttäytymismuutoksiin tai siisteihin lineaariprogressioihin, jotka helposti mukautuvat kaavamaiseen suunnitteluun.

Niillä meistä, joiden tehtävänä on tarjota monipuolisia koulutusmahdollisuuksia suurelle yleisölle, on toinenkin sitoutuminen: Meidän tulee tarjota heille koulutusohjelma, joka tietoisesti ylläpitää vapaata, täysimuotoista osallistumista erityisiin dialogiyhteisöihin, jotka syntyvät oppituntien, kongressien, seminaarien ja muiden koulutusmuotojen kautta. Näiden erikoistehtävänä on mahdollistaa keskustelua, jolla ratkaistaan oikeina pidettyjen mielipiteiden paikkansaäitävyys. Täysimuotoinen osallistuminen näihin keskusteluihin edellyttää erityisjärjestelyjä niiden osalta, jotka eivät voi itse kustantaa osallistumiskulujaan, subventointia naisten, vähemmistöryhmien, vanhusten ja muiden aiemmin syrjittyjen väestöryhmien osalta, erityistä tukea yhteiskunnan piiriin palaaville, sekä aikuisneuvontaa ja -ohjausta. Huomattava osa ohjelmista tulisi kohdistaa yleisiin kysymyksiin - neuvoja siitä, miten ryhdytään yhteiseen toimintaan; opastusta kuluttaja-, terveys- ja äänestyskysymyksissä; aseistariisunta- ja rauhanopintoja; eriävien mielipiteiden kuuluville saattamista; erilaisten poliittisten ja taloudellisten järjestelmien tarkastelua; sekä ohjelmia, joissa tarkastellaan tapoja helpottaa elämänmuutoksia ja itseymmärrystä. Aikuisten lukutaitoa ja muita perustaitoja edistävät ohjelmat ovat myös hyvin tärkeitä. 
Tällaisten koulutusmahdollisuuksien tarjoaminen on ammativelvollisuutemme. Moni koulutussuunnittelija on velvollinen pitämään koulutusohjelmansa taloudellisesti kannattavana; liike-elämän kannattavuusperiaatteita ei tulisi kuitenkaan soveltaa aikuiskasvatukseen. Suosituista kursseista ja ohjelmista saaduilla varoilla tulisi subventoida kursseja, joiden selvänä tehtävänä on tarjota mahdollisimman aikuisopiskelijalle mahdollisuus osallistua vapaaseen, täysimuotoiseen dialogiin. Meidän aikuiskasvattajien tulisi arvioida tällaisia kursseja koulutuksellisten kriteerien pohjalta; aikuiskasvatus heijastaa aina sen yhteiskunnan arvoja, jonka puitteissa se toimii.

On olemassa myös kolmas sitoutuminen, jonka toteuttavat ne aikuiskasvattajat, jotka ensisijaisesti edistävät sosiaalista yhteistoimintaa. Vaikka emme kaikki voi tehdä tästä keskeistä osaa omassa toiminnassamme, on meillä ammattivelvollisuus tuntea tämä alue, ja toimia yhdessä muiden, yhteistoiminnan periaatteen hyväksyvien kanssa. Voimme myös tunnustaa tällä aluaeella keskeisesti toimivien kolleegojemme työn arvon, ja kannustaa heitä tarjoamalla heille vapaaehtoista apuamme.

On selvää, että sosiaalisen yhteistoiminnan tarpeen ymmärtäviä aikuisia tulisi auttaa tutkimaan ongelmakenttäänsä, tiedostamaan kulttuurisidonnaisten uskomusten itsestäänselvyyksiä, kehittämään itsevarmuuttaan, tutkimaan eri toimintamahdollisuuksia, ottamaan selvää resursseista, ennustamaan eri toimintavaihtoehtojen tuloksia, edistämään osallistumista ja johtamistaitoa, sekä arvioimaan olennaisia kokemuksia. Sosiaalisen yhteistoiminnan piirissä toimiville aikuiskasvattajille yhteistoiminta tarjoaa mahdollisuuden, että opiskelijat voivat osallistua kriittisesti pohdiskelevaan, toimivaan tutkimustyöhön, oppia kokemuksistaan samalla, kun he siirtyvät eteenpäin.

Yhteenvetona: mitä, milloin, missä, miksi ja miten opimme määräytyy suureksi osaksi itses- täänselvinä pidettyjen, mutta mahdollisesti epäluotettavien ja vääristyneiden merkitysskeemojen ja -perspektiivien pohjalta. Nämä merkitysrakenteet usein säilytetään sosiaalisten normien, laitostettujen ideologioiden ja kauan yhteiskunnassa vallinneiden tapojen ja tottumusten kautta. Kun opiskelijoiden kriittinen pohdiskelukyky kehittyy, he usein huomaavat, että vääristyneitä merkitysrakenteita esiintyy muuallakin; näin yksityiset ongelmat muuttuvat yleisiksi kysymyksiksi. Tämä johtaa usein halukkuuteen ryhtyä yhteiseen toimintaan muuttaa instituutioita, jotka tukevat vanhoja, vääristyneitä näkökantoja.

Aikuiskasvattajien tulee olla kiinnostuneita koko oppimisprosessista, ei pelkästään siitä osa-alueesta, joka johtaa toimintaan. Sosiaalinen sitoutumisemme sisältää sekä kulttuurisidonnaisten uskomusten tiedostamisen, että opiskelijoiden opastamisen yhteisen toiminnan suunnittelemiseen ja toteuttamiseen. Emme voi kaikki hoitaa molempia tehtäviä. Meidän kaikkien tulee edesauttaa opiskelijoita tiedostamaan ne laajemmat sosiaaliset voimat, jotka vaikuttavat heidän oppimiskokemuksiinsa. Jotkut meistä pystyvät tarjoamaan koulutustilaisuuksia, jotka lisäävät mahdollisuuksia muuttaa katsantokantoja ja aikaansaada sosiaalisia muutoksia. Muutamat meistä voivat erikoistua käsittelemään sosiaalista toimintaa, mutta voimme kaikki jakaa tämän roolin yksityiselämässämme, yksityisinä kansalaisina.

Näkemyksemme saavuttamisen arvoisesta yhteiskunnasta antaa meille kriteerit, joilla voi arvioida sosiaalisen toiminnan suuntaa. Aikuiskasvattajille tämä on oppimisyhteiskunta, jossa jokainen yksilö voi vapaasti ja täysipainoisesti osallistua omaan inhimilliseen pyrkimykseensä ymmärtää omia kokemuksiaan dialogin avulla.

\section{Viitteet}

Goleman, Daniel. 'Insights into self-deception." New York Times Magazine, May 12, 1985, p. 42.

Habermas, Jurgen. The theory of communicative action, Vol. 1: Reason and the Rationalization of Society. Translated by Thomas McCarthy. Boston: Beacon Press, 1984. 